\title{
Analysis of the Effect of Workload on Employee Performance of the Production Operator in Pem Plant Pt. Schneider Electric Manufacturing Batam
}

\author{
$1^{\text {st }}$ Grace Lina Situmorang \\ Administrasi Bisnis Terapan \\ Politeknik Negeri Batam \\ Batam, Indonesia \\ gracelina52@gmail.com
}

\author{
$2^{\text {nd }}$ Rahmat Hidayat, S.AB.,M.AB \\ Administrasi Bisnis Terapan \\ Politeknik Negeri Batam \\ Batam, Indonesia \\ rahmat@polibatam.ac.id
}

\begin{abstract}
This study aims to determine the effect of workload on the employee performance of the production operator at PEM Plant PT. Schneider Electric Manufacturing Batam. In this study there are three variables namely external workload (X1) and internal workload (X2) and employee performance (Y). The samples in this study were 71 respondents using the sampling technique using Slovin formula. Respondents of this study were employees who worked on the Tesys PEM Plant line at PT. Schneider Electric Manufacturing Batam. The data analysis method used in this study is descriptive analysis and multiple linear regression analysis with hypothesis testing, namely t-test (partial) and F-test (simultaneous). From the results of multiple linear regression shows that partially there is an influence on the external workload variable on employee performance and there is no influence on the internal workload variable on employee performance. Simultaneously there are influences on external workload variables and internal workloads on employee performance.
\end{abstract}

Keywords- Workload, External Workload, Internal Workload, Employee Performance

\section{INTRODUCTION}

A. Background

Human resources are important and must be considered by every business activity. According to Ardana, Komang et al (2012) human resources are the most important and most valuable assets or assets that must be owned by an organization. The statement is supported by the fact that human resources are the only elements of the organization that have feelings and reason that are capable of making them the determinants and drivers of other resources. The company's treatment of human resources is certainly also different from other resources, especially in building maximum performance. Motivation, fulfillment of material rights, appropriate work facilities and good workload management are needed to encourage human resources to obtain maximum performance results. Therefore, it is important for a company to manage human resources well.

PT Schneider Electric Manufacturing Batam is one of the big companies with a number of human resources reaching 2,965 in Batamindo Area, Batam. The company engaged in electricity manufacturing has many lines in its production activities. The various lines have different tasks with each other with different work facilities. Every operator who works is given a certain target in conducting production activities, which is the target must be able to be reached by the operator. There are 4 plants in the company, one of which is PEM Plant which is the center of the entire Plant. The PEM Plant consists of five lines detailed in Table 1.

TABLE I.

DATA ON PRODUCTION DEPARTMENT EMPLOYEES

\begin{tabular}{|c|c|}
\hline Line & $\begin{array}{c}\text { Number of } \\
\text { employees }\end{array}$ \\
\hline MCB & 83 \\
\hline Tesys & 243 \\
\hline Kiwi & 96 \\
\hline Harmony & 146 \\
\hline MS2 & 179 \\
\hline TOTAL & $\mathbf{7 4 7}$ \\
\hline
\end{tabular}

Activities carried out in this Plant are production activities based on customer demand. One line that receives the highest demand from consumers is line tesys, which is a request from a Japanese company engaged in automation. The characteristics of consumers from Japanese companies are very different from other consumers, especially in terms of quality assurance. Consumers from Japanese companies request products that are very clean, neat, and without any errors. This consumer demand made the company's management tighten its production activities by installing a special surveillance camera to monitor the operators in doing their jobs so that no items were rejected. This surveillance camera is only placed on the tesys line and makes the operator more burdened, but unfortunately when checking goods by the quality control department, rejecting items are still found. The contributing factors are engine breakdown and factors from operators who experience fatigue, resulting in operators being less concentrated in carrying out production activities. The fatigue experienced by the operator is caused by the operator working under pressure and the demands of the target with a large amount so that the 
operator is too focused on quantity and often does not pay attention to quality anymore.

Seeing the problems faced by line tests, workload is a factor that needs to be considered in relation to employee performance. Workloads are activities that must be completed by employees within a predetermined period of time and generally the tasks charged are not in accordance with the ability of the workforce so that it greatly affects the performance of the employee.

B. Formulation of the problem

The formulation of the problem in this study is:

1. How does the influence of internal workload on the Employee Performance of the production part of the PEM Plant PT. Schneider Electric Manufacturing Batam.

2. How does the external workload influence the Employee Performance of the production section at the PEM Plant PT. Schneider Electric Manufacturing Batam.

3. Simultaneously how the influence of external workload and internal workload on the Employee Performance of the production section at the PEM Plant PT. Schneider Electric Manufacturing Batam.

C. Research purpose

The research purpose in this study is :

1. To find out how the influence of internal workload on the Employee Performance of the production section at the PEM Plant of PT. Schneider Electric Manufacturing Batam.

2. To find out how the influence of external workload on the Employee Performance of the production part of the PEM Plant of PT. Schneider Electric Manufacturing Batam.

3. To find out simultaneously how the influence of external workloads and internal workloads on production part operators at the PEM Plant PT. Schneider Electric Manufacturing Batam.

D. Benefits of research

The benefits of this research are:

1. Through this research, it is expected to be able to benefit science for the leadership of the company PT. Schneider Electric Manufacturing Batam and can be a material consideration and reference in the improvement and development of the company in the future.

2. Helping the writer in applying the knowledge that has been obtained while studying in Batam State Polytechnic by making research reports scientifically and systematically and can add knowledge and insight to the author.

3. It is hoped that it can be a reference for other researchers who will conduct research on human resources in the future.

\section{LITERATURE REVIEW}

\section{A. Definition of Workload}

There are many terms about the workload that has been known since the 1970s. Various different definitions have been put forward by experts so that it is difficult to get a precise conclusion about workload. One definition of workload according to experts is the activities that must be completed by employees within a predetermined period of time (Dhania, 2010).

\section{B. Factors Affecting Expenses}

The factors that influence workload in the research of Soleman \& Aminah (2011) are as follows:

1. External factors are burdens originating from outside the worker's body such as:

a. Tasks are grouped into two, namely tasks that are physical in nature such as workspace layout, work attitude, workspace condition, lifting burden. Tasks that are mental in nature such as the level of complexity of the work, the level of difficulty of the work, the responsibilities given, the emotions of the job.

b. Work organization is a factor that comes from the policies made by the company such as the length of rest periods, work systems, division of work shifts, work time, wage system, organizational structure and so on

c. The work environment is a factor that comes from environmental conditions that are usually used to work and can add to the workload of employees such as a chemical work environment, a physical work environment, a psychological work environment, and a biological work environment.

2. Internal factors are factors that originate from the body of the worker itself as a result of external workload reactions of factors originating in the body due to the reaction of external workloads. The reaction is usually referred to as strain. There are two factors that have the potential to cause stressors, namely somatic factors and psychological factors. Somatic factors include age, body size, gender, health condition, nutritional status, and so on. Psychological factors include motivation, perception, trust, satisfaction, desire, and so on.

\section{Workload Effects}

According to Setiawan (2016) the excessive workload will have the effect of physical and mental fatigue and emotional reactions such as headaches, digestive disorders, and irritability.

While a low workload will cause boredom and a sense of monotonous. Boredom in daily routine work because of too little work or work results in a lack of attention to work will potentially harms and lowers employee performance. 


\section{Definition of Employee Performance}

According to Mangkunegara (2014), employee performance is a comparison of the results achieved with the role of labor per unit time, typically per hour.

E. Factors Affecting Employee Performance

1. Individual factors consisting of:
a. Ability and expertise
b. Background
c. Demographics

2. Psychological factors consisting of:
a. Perception
b. Attitude
c. Personality
d. Learning
e. Motivation

3. Organizational factors consisting of:
a. Resource
b. Leadership
c. appreciation
d. Structure
e. Job design

\section{F. Performance Effects}

According to Umam (2010) there are several effects of the existence of performance, namely:

1. Achieving targets

It's when employees and leaders act effectively with positive energy, to complete their respective tasks and responsibilities in accordance with the directions of the target. So at that time, everyone's positive energy will collaborate and contribute to produce the best work and performance.

2. Employee loyalty

Loyalty has several elements, namely the presence of loyalty, awareness in carrying out the duties and responsibilities, and trying to maintain the good name of the company, because the higher the level of employee loyalty, the better the employee's performance.

3. Training and development

If the better the performance of employees, the easier it is to carry out training and development. Conversely, if the employee's performance gets worse, then the level of the employee's needs will be higher to get training and development.

4. Promotion

Performance can be used as one of the considerations for employee promotion.

5. Be positive

Encourage others to behave positively or improve their levels that are below the standard of performance.

6. Increased organization

Provide a solid basis for policy making in order to organizational improvement.

\section{RESEARCH METHODS}

\section{A. Population and Sample}

Population is all data of our concern in a scope and time that we specify. The population in this study were all production part operators totaling 243 people. Meanwhile for sampling techniques used Slovin formula.

This sampling is carried out with a confidence level of $90 \%$ or a critical value of $10 \%$ so that the sample size can be calculated as follows:

$$
n=\frac{243}{1+243(10 \%)^{2}}=70,84
$$

Based on the above calculations, the sample will be taken as many as 71 (rounded up) production people.

\section{B. Type and Sources Data}

The types and sources of data used in this study primary and secondary data:

\section{Primary Data}

This data can be obtained through survey and observation methods. In this writing the primary data in the form of individual opinion through the distribution of questionnaires to employees of the production section in PEM Plant PT Schneider Electric Manufacturing Batam. The test results are in the form of a calculation.

2. Secondary Data

Secondary data is data obtained from reports or records of company records that can support primary data. The data needed in this study is employee production data in each line production, profile and general description of the company, organizational structure and other data that can support this research.

\section{Data Collection Technique}

Data Collection technique by the author are:

a. Questionnaire

Questionnaires are data collection techniques that are carried out by giving written statements to respondents to get answers to responses and information needed by researchers. To measure the respondents, answers then used approach Likert scale by using four categories : Stongly Agree (4), Agree (3), Disagree (2), and Storngly Disagree (1).

b. Documentation

This technique is used by collecting written data needed, namely documents and written reports of companies to support the data needed to explain the performance problems of employees at PT. Schneider Electric Manufacturing Batam.

c. Observation

Observation is a technique of collecting data by observing or observing directly the object of research, namely the production part operator who is carrying out the production process. 


\section{RESULTS AND DISCUSSION}

A. Validity and Reliability

\section{a. Validity}

Validity test can be done by making a correlation between the scores of questions with a total score of variables. Questionnaire questions are valid if the value of r-count> r-table.

TABLE II

VALIDITY TEST RESULTS

\begin{tabular}{|c|c|c|c|}
\hline Item & r-count & r-table & Conclusion \\
\hline X1.1 & 0,648 & 0,2335 & Valid \\
\hline X1.2 & 0,596 & 0,2335 & Valid \\
\hline X1.3 & 0,691 & 0,2335 & Valid \\
\hline X1.4 & 0,247 & 0,2335 & Valid \\
\hline X1.5 & 0,630 & 0,2335 & Valid \\
\hline X1.6 & 0,517 & 0,2335 & Valid \\
\hline X1.7 & 0,660 & 0,2335 & Valid \\
\hline X1.8 & 0,672 & 0,2335 & Valid \\
\hline X1.9 & 0,730 & 0,2335 & Valid \\
\hline X1.10 & 0,663 & 0,2335 & Valid \\
\hline X1.11 & 0,709 & 0,2335 & Valid \\
\hline X2.1 & 0,555 & 0,2335 & Valid \\
\hline X2.2 & 0,575 & 0,2335 & Valid \\
\hline X2.3 & 0,439 & 0,2335 & Valid \\
\hline X2.4 & 0,474 & 0,2335 & Valid \\
\hline X2.5 & 0,637 & 0,2335 & Valid \\
\hline X2.6 & 0,563 & 0,2335 & Valid \\
\hline X2.7 & 0,654 & 0,2335 & Valid \\
\hline Y1.1 & 0,768 & 0,2335 & Valid \\
\hline Y1.2 & 0,806 & 0,2335 & Valid \\
\hline Y1.3 & 0,799 & 0,2335 & Valid \\
\hline Y1.4 & 0,654 & 0,2335 & Valid \\
\hline Y1.5 & 0,799 & 0,2335 & Valid \\
\hline Y1.6 & 0,877 & 0,2335 & Valid \\
\hline Y1.7 & 0,821 & 0,2335 & Valid \\
\hline & & & \\
\hline
\end{tabular}

It can be seen from all score items from each instrument validity test in Table 2 is $r$-count $>$ r-table with $r$-table value $(0.2335)$ which means that each instrument of statement item is declared valid. The r-table value is sought at $5 \%$ significance with the equation $\mathrm{Df}=\mathrm{n}-\mathrm{k}=$ $71-2=69$.

\section{b. Reliability}

This study uses Alpha Cronbach technique. A construct or variable is said to be reliable if the value of Cronbach Alpha> 0.60 .

TABLE III

RELIABILTY TEST RESULTS

\begin{tabular}{|c|c|c|c|}
\hline \multirow{2}{*}{ Variable } & \multicolumn{3}{|c|}{ Reliability } \\
\cline { 2 - 4 } & $\begin{array}{c}\text { Alpha } \\
\text { Cronbach }\end{array}$ & $\begin{array}{c}\text { Cut off Alpha } \\
\text { Cronbach }\end{array}$ & Conclusion \\
\hline $\begin{array}{c}\text { Extenal Workload } \\
\text { (X1) }\end{array}$ & 0,748 & 0,6 & Reliable \\
\hline $\begin{array}{c}\text { Internal Workload } \\
(\mathrm{X} 2)\end{array}$ & 0,709 & 0,6 & Reliable \\
\hline $\begin{array}{c}\text { Employee } \\
\text { Performance (Y) }\end{array}$ & 0,792 & 0,6 & Reliable \\
\hline
\end{tabular}

Viewed from the results of data processing that Cronbach Alpha value for the External Workload variable $(\mathrm{X} 1)$ is $(0.748>0.6)$, Internal Workload $(\mathrm{X} 2)$ is (0.709> 0.6), and Employee Performance $(\mathrm{Y})$ is $(0.792>$ $0.6)$. Thus it can be concluded that the measurement item statement $(\mathrm{X} 1),(\mathrm{X} 2)$, and $(\mathrm{Y})$ can be trusted (reliable) and the data is feasible to be used in the subsequent analysis.

\section{B. Classic assumption test}

a. Normality test

A simple statistical test that is often used to test the assumption of normality is to use the normality test from Kolmogorov Smirnov. The normal test method for data distribution is done by looking at the variable significance value, if it is significantly greater than alpha $10 \%(0.1)$, then it shows normal data distribution.

TABLE IV

NORMALITY TEST RESULTS

\begin{tabular}{|l|c|}
\hline & $\begin{array}{c}\text { Unstandardized } \\
\text { Residual }\end{array}$ \\
\hline Kolmogorov-Smirnov Z & 1,024 \\
\hline Asymp. Sig. (2 tailed) & 0,245 \\
\hline
\end{tabular}

To analyze the Kolmogorov Smirnov value in Table 4, it can be concluded that the data has a normal distribution because the Kolmogorov Smirnov value has a significance level of $0.245>0.05$.

b. Multicollinearity test

Multicollinearity test is used to test whether there is a correlation between independent variables in a regression model. Multicollinearity seen from tolerance value and variance inflation factor (VIF) with decision making criteria is if the tolerance value $>0.10$ and VIF value $<10.00$ means that there is no multicollinearity in the regression model.

TABLE V

MULTICOLLINEARITY TEST

\begin{tabular}{|c|c|c|c|}
\hline \multirow{2}{*}{ Model } & \multicolumn{2}{|c|}{ Collinearity Statistics } & \multirow{2}{*}{ Conclusion } \\
\hline & Tolerance & VIF & \\
\hline \multicolumn{4}{|l|}{ (Constant) } \\
\hline $\begin{array}{l}\text { X1_External } \\
\text { Workload }\end{array}$ & 0.806 & 1.241 & $\begin{array}{c}\text { No } \\
\text { Mullticolinearity }\end{array}$ \\
\hline $\begin{array}{l}\text { X2_Internal } \\
\text { Workload }\end{array}$ & 0.806 & 1.241 & $\begin{array}{c}\text { No } \\
\text { Mullticolinearity }\end{array}$ \\
\hline
\end{tabular}

Based on Table 5, each variable has a tolerance value > 0.10 and VIF value $<10$, so it can be concluded that there is no multicollinearity between independent variables in this regression model.

\section{c. Heterocedasticitiy Test}

Heterocedasticity aims to test whether a group has the same variance between members or not (Rumengan, 2013). Heterocedasticity can be seen from the residual unstandardized value if it has a significance value (sig 2 tailed) greater than 0.05 means that there is no heterocedasticity. 
TABLE VI

HETEROCEDASTICITY TEST

\begin{tabular}{|c|c|c|}
\hline Variable & $\begin{array}{c}\text { Unstandarized } \\
\text { Residual }\end{array}$ & Conclusion \\
\hline $\begin{array}{c}\text { External Workload } \\
\text { (X1) }\end{array}$ & 0.935 & No Heterocedasticity \\
\hline $\begin{array}{c}\text { Internal Workload } \\
\text { (X2) }\end{array}$ & 0.545 & No Heterocedasticity \\
\hline
\end{tabular}

Based on Table 6 it can be seen that the correlation between the external workload variable and internal workload with unstandardized residuals has a significance value (sig 2 tailed) greater than 0.05 or can be seen in the table above shows that the value 0.935 External Workload (X1) and 0.545 greater than 0.05 . So it can be concluded that these variables have no heterocedasticity.

\section{Multiple Linear Regression Analysis}

TABLE VII

COEFFICIENT TEST RESULTS

\begin{tabular}{|c|c|c|c|c|c|}
\hline $\begin{array}{c}\text { Dependen } \\
\text { Variable }\end{array}$ & $\begin{array}{c}\text { Independen } \\
\text { Variable }\end{array}$ & $\begin{array}{l}\text { Regression } \\
\text { Coefficient }\end{array}$ & t-count & Sig. & Conclusion \\
\hline \multirow{2}{*}{$\begin{array}{c}\text { Kinerja Karyawan } \\
\text { (Y) }\end{array}$} & $\begin{array}{c}\text { Beban Kerja } \\
\text { Eksternal (X1) }\end{array}$ & 0,407 & 3,526 & 0,001 & Signifikan \\
\hline & $\begin{array}{l}\text { Beban Kerja } \\
\text { Internal (X2) }\end{array}$ & 0,187 & 1,618 & 0,110 & Tidak Signifikan \\
\hline Constant & 8,898 & & & & \\
\hline $\mathrm{R}$ & 0,518 & & & \multicolumn{2}{|r|}{ Nilai Kritis } \\
\hline R Square & 0,268 & & & $\mathrm{t}$ tabel & 1,99547 \\
\hline Adjusted R Square & 0,247 & & & f tabel & 3,13 \\
\hline F Hitung & 12,455 & & & & \\
\hline
\end{tabular}

From the table above, the coefficient test regression analysis equation can be obtained as follows.

$$
Y=8,898+0,407 X 1+0,187 X 2
$$

A constant of 8,898 shows the Employee Performance of the Operator in the PEM Plant of PT. The Schneider Electronic Manufacturing Batam (Y) will experience an increase if the External Workload and Constant Internal Workload factors, meaning that there is an increase in $\mathrm{Y}$ of 8.898. The influence of each of the factors that influence Employee Performance is:

1. Regression coefficient External Workload (X1) is 0.407. This shows the magnitude of the influence of these variables on Employee Performance. A positive sign indicates a positive direction coefficient means that if the External Workload variable is increased, the Employee Performance of the Production Operator will also increase, assuming other variable factors are constant

2. The regression coefficient of Internal Workload (X2) is 0.187 . This shows the magnitude of the influence of these variables on Employee Performance. A positive sign indicates a positive direction coefficient means that if the Internal Workload variable is increased, the Employee Performance of the Production Operator will also increase, assuming other variable factors are constant.

\section{Hypothesis testing}

a. T Test Results (Partial)
The $t$ statistical test is carried out to determine the effect of each independent variable on the dependent variable partially based on Table 7 above, the following results are obtained:

1. Testing the First Hypothesis (H1)

The first hypothesis is to find out whether the External Workload variable has an influence on the Employee Performance of Production Operators in the PEM Plant PT. Schneider Electric Manufacturing Batam. From the results of the analysis, it is known that the value of the calculated $t$ of the External Workload variable is 3.526 with a sig value of 0.001 . This value is greater than t-table 1.99547 ( $\mathrm{t}$-count $>\mathrm{t}$ table) and sig smaller than 0.05 . Then it can be concluded that $\mathrm{H} 1$ states "There is the Effect of External Factors (X1) on Employee Performance of Production Operators in PEM Plant PT. Schneider Electric Manufacturing Batam" is truly tested. This is not contained in the Empirical Study, so that in the future it can be used as a reference or comparison for further research.

2. Testing of the Second Hypothesis (H2)

The second hypothesis is to find out whether there are internal workload variables that have an influence on the Employee Performance of Production Operators in the PEM Plant PT. Schneider Electric Manufacturing Batam. From the results of the analysis, it is known that the value of the calculated $t$ of the Internal Workload variable is 1.618 with a sig value of 0.110 . This value is smaller than t-table 1.99547 (t-count $>$ t-table) and sig greater than 0.05 . So it can be concluded that $\mathrm{H} 2$ states "There is an Influence of Internal Factors (X2) on Employee Performance of Production Operators at PEM Plant PT. Schneider Electric Manufacturing Batam" is not tested. This is not contained in the results of previous studies, so that the Internal Workload variable can be tested again for the next study.

\section{b. F Test Results (Simultaneous)}

The F test is a test of the coefficients simultaneously. This test is performed for all independent variables contained in the model together (simultaneous) on the dependent variable, the following results are obtained:

1. Testing of the Third Hypothesis (H3)

The third hypothesis is to test whether the External Workload and Internal Workload factors jointly affect the Employee Performance of Production Operators in the PEM Plant PT. Schneider Electric Manufacturing Batam. The test results obtained in Table 4.13 show that Fcount is 12.455> Ftable 3.13 with a significance value of $0,000<0.05$ because the significance value is smaller than 0.05 . Then it can be concluded that H3 states "There is a Simultaneous Effect of External Workload Factors and Internal Workloads on Employee Performance of Production Operators at PEM Plant PT. Schneider Electric Manufacturing Batam "is truly tested. The results of this test are found in the Empirical Study, so that in the future it can be used as a reference for further research. 


\section{E. Discussion}

This study aims to examine and analyze how the influence between the independent variables namely External Workload (X1) and Internal Workload (X2) on the dependent variable is Employee Performance (Y) at PEM Plant PT. Schneider Electric Manufacturing Batam. The populations in this study were employees of the line tesys Plant production operator PT. Schneider Electric Manufacturing Batam.

\section{a. The Effect of External Workload Variables on Employee Performance}

Based on the results of data processing using SPSS External Workload variable has a value of 3.526 greater than t-table 1.99547 with a significance value of 0.001 smaller than the value of $\alpha=0.05$. It can be concluded that partially the External Workload variable has a positive and significant influence on Employee Performance in the part of the production operator. These results provide evidence that the variable External Workload has a positive and significant effect on Employee Performance of the production operator, so the first hypothesis (H1) is accepted. This is in line with Gulo's research (2015) entitled The Effect of Workload on the Performance of Employees in the Production Section at PT. Super Pakindo Manufacturing Batam. The results of the research conducted stated that there were positive and significant influences.

\section{b. The Influence of Internal Workload Variables on Employee Performance}

Based on the results of data processing using SPSS Internal Workload variable has a value of $1.618 \mathrm{t}$-count smaller than t-table 1.99547 with a significance value of 0.110 greater than the value of $\alpha=0.05$. It can be concluded that partially the variable Internal Workload does not have a positive and insignificant influence on Employee Performance in the part of the production operator. These results provide evidence that the variable Internal Workload does not affect the Employee Performance of the production operator section, thus the second hypothesis $(\mathrm{H} 2)$ is rejected. This is not in line with the research of Irawati \& Carollina (2017) entitled Analysis of the Effect of Workload on Employee Performance of Production Operators at PT. Giken Precision Indonesia. The results of the research conducted stated that there were positive and significant influences.

\section{c. Effect of External Workloads and Internal Workloads on Employee Performance}

Based on the results of multiple regression analysis it's show that external workload and internal workload simultaneously gave influence on Employee Performance. These results are obtained from the value of Fcount $>$ Ftable (12.455> 3.13). This result provides evidence that the variable External Workload and Workload Internal simultaneously influences the Employee Performance of production operator parts, thus the third hypothesis $(\mathrm{H} 3)$ is accepted. This is in line with the research of Irawati \& Carollina (2017) entitled Analysis of the Effect of Workloads on Employee Performance of Production Operators at PT. Giken Precision Indonesia. Internal workload and external workload have an effect simultaneously on the performance of the operator's employees.

\section{CONCLUSIONS \& RECOMMENDATIONS}

\section{A. Conclusions}

Based on the analysis and discussion of the results of the study:

1. There is a significant effect between the variable external workload (X1) partially on the performance of employees at PT. Schneider Electric Manufacturing Batam. Thus the first hypothesis is accepted.

2. There is no significant effect between the variable internal workload (X2) partially on the performance of employees at PT. Schneider Electric Manufacturing Batam. Thus the second hypothesis is rejected.

3. Based on the research that has been done, the workload factors between external workload (X1) and internal workload (X2) simultaneously have a significant effect on employee performance. Thus the third hypothesis is accepted.

\section{B. Recommendations}

Based on the above conclusions, the suggestion to be used as input to the company:

1. It is expected that the company can pay attention to the tasks given so it is not too difficult and in accordance with the capabilities of employees so that employees do not feel burdened in doing their jobs and do not cause employee performance to decline.

2. It is expected that the company can maintain a comfortable and safe work environment and spatial environment for employees so that it can facilitate employees in moving and doing their jobs.

3. It is expected that the company can pay attention to the rest time given to employees, because if employees have sufficient rest time, the employee's performance will also increase.

4. It is expected that the company can maintain and improve services related to internal workload factors such as conducting training, providing motivation by holding promotions or giving awards, and providing adequate facilities. This is useful for reducing fatigue and saturation of employees while working.

5. For further researchers who are interested in continuing this research, it is expected to be able to develop, namely by using other variables that are more varied..

\section{ACKNOWLEDGMENTS}

1. We thank The One Almighty God who has given a favor healt, patience and His gift to writers. The preparation of this thesis can not be separated from the guidance and 
help of various parties. On this occasion, the author woould like to thank :

2. Director of Batam State Polytechnic, Mr. Priyono Eko Sanyoto.

3. Assistant Director of Academic and Education of Batam State Polytechnic, Mr. Uuf Brajawidagda. S.T., M.T., $\mathrm{Ph} . \mathrm{D}$.

4. Chair of the Department of Business Management, Ms. Dwi Kartikasari, S.T, M.BA.

5. Chair of the Applied Business Administration Study Program, Mr Rahmat Hidayat, S.AB, M.AB.

6. Mr Rahmat Hidayat, S.AB, M.AB as a Supervisor who has been full of patience to provide guidance, motivation, and direction in perfecting this thesis.

7. Ms. Rusda Irawati, S.E., M.Sc., as the 1 Examination Lecturer who has provided many inputs, directives, guidance, motivations, criticisms and constructive suggestions in this thesis examination process.

8. Ms. Maryani Septiana, S.Sos., M. Hum, as Testing Lecturer 2 who has provided many input, direction, guidance, motivation, criticism and constructive suggestions in this thesis examination process.

9. Business Management Lecturers and Staff, especially Business Administration Study Program, thank you for 4 years of knowledge and guidance as part of Business Administration

10. Parents of writers, for all prayers and encouragement both in terms of material and non-material.

11. The brother and sister of the writer, for all their support, encouragement, and assistance in helping the author complete the thesis.

12. Companions of Applied Business Administration Study Program 2015. Thank you for being together for 4 years.

13. All parties who have supported and assisted in the preparation of this thesis that the author cannot mention one by one.

\section{REFERENCES}

[1] Ardana, Komang, \& Dkk. (2012). Manajemen Sumber Daya Manusia. Bandung: Graha Ilmu.

[2] Asamani, J. A., Amertil, N. P., \& Chebere, M. (2015). The Influence of Work Levels on Performance in a Rural Hospital. British Journal of Healthcare Management, Vol. 21, No. 12.

[3] Chandra, R., \& Adriansyah, D. (2017). Pengaruh Beban Kerja dan Stres Kerja terhadap Kinerja Karyawan pada PT. Mega Auto Central Finance Cabang di Langsa. Jurnal Manajemen dan Keuangan, Vol. 6 , No. 1.

[4] Dhania, D. R. (2010). Pengaruh Stres Kerja, Beban Kerja Terhadap Kepuasan Kerja (Studi pada Medical Representatif di Kota Kudus). Jurnal Psikologi Universitas Muria Kudus, Volume I, No. 1, Desember 2010.

[5] Gulo, T. M. (2015). Pengaruh Beban Kerja Terhadap Kinerja Karyawan Bagian Produksi pada PT. Super Pakindo Manufacturing Batam. https://repository.polibatam.ac.id/.

[6] Anurogo, W., Sari, L. R., Lubis, M. Z., Pamungkas, D. S., \& Situmorang, A. D. L. (2018, October). An Integrated Comparative Approach to Estimating Forest Aboveground Carbon Stock Using Advanced Remote Sensing Technologies. In 2018 International Conference on Applied Engineering (ICAE) (pp. 1-6). IEEE.
[7] Irawati, R., \& Carollina, D. A. (2017). Analisis Pengaruh Beban Kerja Terhadap Kinerja Karyawan Operator pada PT Giken Precision Indonesia. Jurnal Inovasi dan Bisnis, Vol. 5 No. 1, hlm. 57-58.

[8] Mangkunegara, A. A. (2014). Manajemen Sumber Daya Manusia Perusahaan. Bandung: Remajaj Rosdakarya.

[9] Marlina, T. (2015). Pengaruh Beban Kerja Terhadap Kinerja Karyawan Bagian Produksi pada PT. Super Pakindo Manufacturing Batam. Skripsi Manajemen Bisnis Program Studi Administrasi Bisnis Politeknik Negeri Batam.

[10] Rumengan. (2013). Metodelogi Penelitian. Bandung: Cipta Pustaka

[11] Setiawan, D. P. (2016). Pengaruh Beban Kerja dan Lingkungan Kerja Terhadap Kinerja Karyawan PT. Macanan Jaya Cemerlang KlatenJawa Tengah-Indonesia. Skripsi Manajemen Fakultas Ekonomi Universitas Negeri Yogyakarta

[12] Soleman, \& Aminah. (2011). Analisis Beban Kerja Ditinjau dari Faktor Usia Dengan Pendekatan Recommended Weith Limit (Studi Kasus Mahasiswa Unpatti Poka). Jurnal Arika, Vol. 05, No. 02 (Agustus 2011)

[13] Sugiyono. (2011). Metode Penelitian Kuantitatif, Kualitatif dan R\&D. Bandung: Alfabeta.

[14] Sujarwanto. (2016). Pengaruh Motivasi Kerja dan Beban Kerja Terhadap Kinerja Karyawan Bank BTN Yogyakarta. Skripsi Fakultas Ekonomi Universitas Negeri Yogyakarta.Wilson, R. G., \& Rouse, W. R. (1972). Moisture and temperature limits of the equilibrium evapotranspiration model. Journal of Applied Meteorology, 11(3), 436-442.

[15] Tjiabrata, F. R., Lumanaw, B., \& Dotulong, L. O. (2017). Pengaruh Beban Kerja dan Lingkungan Kerja Terhadap Kinerja Karyawan PT. Sabar Ganda Manado. Jurnal EMBA, Vol.5 No.2 Hal. 1570-1580.

[16] Umam, K. (2010). Perilaku Organisasi . Bandung: CV Pustaka Setia. 